\title{
INVESTING AND INTENTIONS IN FINANCIAL MARKETS
}

\author{
CARL DAVID MILDENBERGER \\ University of St. Gallen \\ Original scientific article - Received: 04/04/2019 Accepted: 10/08/2019
}

\begin{abstract}
Ethical investors are widely thought of as having two main goals. The negative goal of avoiding their investments to be morally tainted. The positive goal to further a certain ethical value they embrace or some normatively laden idea they hold by investing their money in a certain company. In light of these goals, the purpose of this paper is to provide an account of how we can explicitly include investors' intentions when conceiving of ethical investment. The central idea is that an investor's intentions may act as both a negative and a positive qualifier for making investing ethical. If we subscribe to this account, there are interesting upshots with respect to how ethical investing compares to ethical giving as effective altruists construe it.
\end{abstract}

Keywords: ethical investment, intentions, negative qualifier, positive qualifier, ethical giving

\section{Introduction}

It is a common idea in the literature on ethical investment that ethical investors are motivated by two main goals when investing ethically - one negative and one positive (e.g. Mackenzie and Lewis 1999; Hudson 2005; Beal, Goyen, and Phillips 2005; von Wallis and Klein 2015; de Bruin et al. 
2018). ${ }^{1}$ On the one hand, they want to avoid that their investments are somehow morally tainted. Hudson describes that they feel the duty "of notprofiting from bad corporate behavior" $(2005,641)$. Lewis and Mackenzie (2000) find that $84 \%$ of ethical investors wish to avoid harmful companies, and that $69 \%$ want their investments to be ethically clean. On the other hand, ethical investors want to support companies with a positive impact on society. In the study by Lewis and Mackenzie, $73 \%$ of ethical investors reported this motive. Beal et al. find one main motive of ethical investors to be to positively "contribute to social change" $(2005,67)$.

Given this clear picture, it is somewhat surprising that ethical investors' intentions do not have a more systematic place in ethical investment theory or get a more explicit treatment in the literature. To give just two examples: in an influential paper, Irvine $(1987,238)$ states that some people think investors' intentions matter in judging investments - but does not go into more detail than that. Sandbu (2012), by contrast, elaborates on delegated agency and collective intention, but does not develop the more basic picture of how individuals' intentions play a role in ethical investment. The purpose of this paper is to do just this, i.e. to provide an account of how we can explicitly include investors' intentions when conceiving of ethical investment. The central idea is that an investor's intentions may act as both a negative and a positive qualifier for making investment ethical.

After briefly leading into the topic of qualifiers of ethical investment (Section 1), I shall argue that intentions play a role when judging investors who want to avoid morally tainted investments (Section 2). Namely, in analogy to other cases of people somehow being involved in somebody else's wrongdoing, whether a certain investor exhibits a mens rea makes for a meaningful qualifier of ethical investment. I proceed to argue that the very action of ethical investing with the goal to have a positive impact on society is best understood as an action which requires a double intention (Section 3); namely, the intention to create a positive financial return for oneself as well as the intention to promote some value one embraces or some normatively laden idea one holds. I conclude by highlighting two upshots of my suggested role of intentions in ethical investment theory (Section 4). I develop these upshots by means of a comparison with practices of ethical giving as construed by effective altruists (e.g. MacAskill 2015; Singer 2015; Pummer 2016). On the negative side, I show

\footnotetext{
${ }^{1}$ I would like to thank Dieter Thomä, Thomas Beschorner, Emmanuel Alloa, Michael Festl, Federica Gregoratto, Thomas Telios, and Lukas Peter - as well as two anonymous referees - for many helpful comments on earlier versions. I gratefully acknowledge support from the Research Commission of the University of St. Gallen (Grant No. 1031523), which helped me in preparing this work.
} 
that addressing the issues of agent-neutrality and demandingness is more complicated when we aim to invest rather than to give ethically. On the positive side, however, taking into account intentions also helps us to acquire a more honest perspective on what promoting ethical causes by allocating our money to them means and entails.

My goal in this essay is not to convince committed consequentialists that intentions matter for evaluating whether certain investments are ethically right. It is better understood as an effort to highlight how we may make room for intentions in existing approaches to ethical investment, if we think they do play a role. That being said, notably Section 3 may be read as purely conceptual effort of developing an idea of what ethical investment with the positive goal of furthering a certain good is; i.e. as putting forward metaphysical considerations that are not necessarily tied to questions of normative evaluation.

\section{Ethical Investment}

When we speak of investing something this means that we as investors expect some kind of positive return for ourselves in the future from this investment. ${ }^{2}$ Generally speaking, the return on an investment might be of material (notably: financial) or immaterial nature. We invest in our own education, e.g. by attending university, to acquire knowledge and to make us more employable. Some parents invest in their children, so that they can show them off at a later time. Or we may invest in a certain stock to create some financial return.

This future return on investment plays a crucial role in distinguishing investing money from donating money, or from doing nothing with our money. Consider that when you invest money, you expect a return for yourself. Thus, the return on investment is not the same as the benefits secured by others, namely those who profit from, say, charitable giving. Also, when you donate money, you do not expect any return for yourself other than maybe a mental return of feeling good about yourself. ${ }^{3}$ But even this "warm glow" sometimes associated to giving money to a charity is not

\footnotetext{
${ }^{2}$ An investment turning out to create a negative return still counts as an investment. But it typically will be the expected positive return which motivates the investment in the first place.

${ }^{3}$ As Mackenzie and Lewis (1999) find in their study of ethical investors' motivations, ethical investors are well aware of this difference. For instance, they quote one investor who explains his motives like follows. "We felt we had some spare cash. . . . if it went down the plug hole then it wouldn't be that disastrous and we felt it was a good thing to put money into it. I saw it more as a donation I think than an investment probably" $(1999,445)$.
} 
the same as a return on investment - as it is felt immediately rather than realized in the future. Finally, as hiding cash under our pillow does not generate any future cash flows, doing so does not count as investing money. For reasons of simplicity, let us focus on a straightforward case of financial investment in the following: investing your money by buying publicly traded shares of a certain corporation on the stock market, expecting a positive financial return, e.g. in the form of dividend payments or a rising stock price.

What could qualify such financial investment as ethical? In line with the two main goals of ethical investors, two qualifiers suggest themselves one positive, one negative. ${ }^{4}$ Either, ethical investments are those financial investments which are in no way morally tainted. The ethical idea here may be described as two-part. On the one hand, since the financial return to ourselves is an instance of us profiting from what a certain company does, we want this return to be clean. On the other hand, we do not want the money we invest to contribute to ethically dubious corporate practices. Generally speaking, we satisfy this qualifier if we neither passively profit from nor actively assist in ethically dubious operations, i.e. if the company we invest in is ethically clean.

Alternatively, we might say that ethical investments are those financial investments which further some value we embrace or some normatively laden idea we hold. The ethical idea underlying this qualifier is not so much a defensive one (to prevent bad things) but a productive one (to further good things). We do not merely want the company's operations to be ethically clean. We want them to actively contribute something to a certain ethical cause.

Historically speaking, it seems fair to say that the main theoretical efforts have been directed at understanding how to conceive of an ethically clean investment, i.e. how we can avoid investments in companies that are perceived to be ethically problematic (de Bruin et al. 2018). Irvine (1987) argues that the problem lies not so much with financially benefitting from bad companies, but with investors enabling companies to do wrong (but cf. also Larmer 1997; Langtry 2002). Sandbu (2012), by contrast, thinks that what makes certain investments morally objectionable is neither benefitting from nor enabling corporate wrongdoing, but being complicit in it. But there also have been notable efforts to make sense of the ethics in ethical investment by focusing on the good ethical investors can do by "using their financial powers to promote positive societal goods, such as

\footnotetext{
${ }^{4}$ Nothing inherently speaks against the idea that a combination of the two qualifiers is possible - or potentially even desirable.
} 
social justice and environmental sustainability" (de Bruin et al. 2018). This can be done, for instance, by only making investments in certain industries known for (or promising to be) creating sustainable energy solutions. Alternatively, one might try to actively use one's influence as a shareholder to push corporate management in a certain direction (e.g. Mackenzie 1997; Sandberg 2008; 2011; Leys, Vandekerckhove, and Van Liedekerke 2009).

\section{Intentions as a Negative Qualifier for Ethical Investment}

Given that the discussion surrounding negative qualifiers of ethical investment emphasizes how we are not to passively profit from or actively assist in corporate wrongdoing, there is a natural place to integrate considerations about the ethical investor's intentions. Namely, by drawing an analogy to the literature which discusses, quite generally speaking, how we are to morally evaluate somebody's being involved in somebody else's wrongdoing. Especially in legal philosophy, there is a rich literature as to how the intentions of him who benefits from, enables, or is complicit in wrongdoing are morally and legally relevant (e.g. Duff 1990; 2007; Moore 2007; 2009). This is because determining solid grounds for accomplice liability is crucial with respect to the legal doctrine of aiding and abetting.

If we combine ethical investment theory discussing moral taint and common themes in accomplice liability theory, what we get is a more complete picture. The more objective factors of moral taint - i.e. whether one benefits from, enables, or is complicit in wrongdoing - are complemented with more subjective factors - like the "accomplice's" intentions. Applying, for instance, Duff's (1990) insights about accomplice liability in the context of ethical investing, here is an example how such a combination might look like.

Suppose an investor buys shares of a company (and subsequently receives dividend payments from this company) which simply dumps nuclear waste in the sea. This is an example of a "directly evil" company in Irvine's $(1987,234)$ terms. Following Duff, in this case there are four different scenarios of how this objectively morally tainted investment might be subjectively morally tainted - or excused. For intuitively it does make a normative difference whether the investor

(i) intends to assist the company; i.e. he wants the nuclear waste to be dumped in the sea and his investment to make a contribution towards this practice,

(ii) intentionally assists the company; i.e. he does not want the nuclear waste to be dumped in the sea, but he still has a stake 
in the company being able to successfully do so (e.g. because this increases revenues and thus dividend payments) and wants to support this practice by investing in the company,

(iii) knowingly assists the company; i.e. he does not intend that his investment will help the company to dump the nuclear waste, but foresees that it will do so, or

(iv) unknowingly assists the company; i.e. by investing his money he assists the company in its practice of dumping the nuclear waste, but he did not foresee this effect of his investment.

What this classification does is to describe the different levels of mens rea the investor might exhibit. The mens rea of him who profits from or aids and abets certain wrongdoings is, in turn, a major factor in most legal systems as to whether that person should be held responsible. ${ }^{5}$ The straightforward analogy to other cases of being involved in wrongdoing and how neatly the two areas complement each other make for strong arguments why this constitutes a good systematic place for intentions in ethical investment theory.

If we accord intentions the role of an additional negative qualifier of ethical investment, several different scenarios of how the two qualifiers might combine become possible. The one in which an ethical investor tries to subjectively excuse an objectively morally tainted investment by pointing to his lack of mens rea strikes me as the empirically most relevant one. It is also the one Irvine $(1987,238)$ briefly mentions. But there are other options.

Suppose a big institutional investor buys a significant number of shares of a hitherto ethically clean tech corporation - which just publicly announced it is considering using its knowledge for producing innovative weapon systems. Further suppose that the investor explicitly buys the stock to signal to the corporation that it endorses its plans to go into the arms business. Why? Because this promises huge dividend payments. As it turns out, the tech corporation eventually decides against producing the weapon system. It thus remains an objectively morally untainted corporation. Yet, it would seem strange to consider the institutional investor's investment to be completely clean. The subjective moral taint due to the investor's intentions seems sufficient to forbid the conclusion that this particular

\footnotetext{
${ }^{5}$ While in most jurisdictions satisfying either (i) or (ii) is required for being found guilty of aiding and abetting, in some jurisdictions satisfying (iii) is enough (Duff 1990). The situation also tends to be evaluated differently, if we were not considering a "directly evil" company, but an "indirectly evil one" (Irvine 1987, 234), as this increases the distance between the investor and the wrongdoing.
} 
investment is morally untainted; even if the investor never profited from morally tainted corporate practices.

In yet a different scenario, the investment of those who buy "sin stocks" might be found to not only be objectively morally tainted, but on top subjectively so. If the investor consciously and willingly buys these stocks with the intention to promote, say, tobacco consumption, one might reach this conclusion. Finally, one might assume the position that only those investments which are neither objectively nor subjectively tainted should be considered fulfilling the negative qualifier of ethical investment. ${ }^{6}$

Apart from the seamless integration and the force of the analogy, there is yet another reason which speaks in favor of letting intentions play a role as regards the negative qualifier. Consider that exclusively basing the moral evaluation of an investment on how the investor passively profits from or actively assists in corporate wrongdoing puts considerable weight on how closely the investor is connected to the wrongdoing. Given the loose connection between individual stock purchases and corporate practices, one might reasonably argue that the idea of objective moral taint is actually weak. An investor might ask: "Why should I be blamed for a particular investment, if me buying some shares actually has no effect on what the corporation does?"

What this investor has in mind when asking this question are two typical, general objections to the practice of ethical investing (Hudson 2005, 64553; Sandbu 2012, 100-101). First, the old stock-objection; i.e. the thought that the investor does not in fact give the company money. Financial markets for the most part are secondary markets, in which investors do not give money directly to the corporation, but rather to the previous owner of the shares. This makes for a less direct connection between the investor's money and the company's actions. Second, the small purchase-objection; i.e. the idea that individual investors do not possess enough market power to change stock prices. This makes it exceedingly difficult for investors to influence corporate policies.

Irvine $(1987,240-42)$, for one, makes some efforts to refute both objections. He holds that investors might only buy old stock, but that raising the demand for old stock certainly is a factor in creating new stock offerings - in which the company more directly gets money from its

\footnotetext{
${ }^{6}$ Just how we should weigh objective and subjective factors of moral taint when reaching an all-things-considered evaluative judgment about a certain investment is yet a different question; probably one which does not allow for a general answer but needs to be decided on a case-by-case basis. In any case, this issue is beyond the scope of this paper.
} 
investors. Also, he holds that what morally matters is not so much whether my investment does make a difference, but what would happen if everybody acted the way I do.

I think Irvine's replies are successful to the extent that they show that investors cannot simply deny ethical responsibility for their investments altogether. Even in light of financial markets largely being secondary markets in which most investors possess no market power, it does make sense to speak of objectively morally tainted investments. At the same time, given the typically minimal ways in which one investor might profit from or assist in corporate wrongdoing, it does make sense to think about alternative ways in which investments might be morally tainted. One thing this allows us to do, is to come up with a stronger case in favor of holding investors responsible. Objective moral taint might be weak. But if paired with a certain recklessness or negligence on the investor's part, i.e. with a certain level of mens rea, we have a stronger moral hold on unethical investors.

\section{Intentions as a Positive Qualifier for Ethical Investment}

A natural starting point to make sense of ethical investors' stated goal to further some ethical cause with their investment is to say that they want to do two things at once (cf. Lewis and Mackenzie 2000; Beal, Goyen, and Phillips 2005; Hudson 2005). By investing money, they want to secure a future financial return for themselves - often because fiduciary duties require them to do so. But, by investing money, they also want to further some ethical cause.

In economic terminology, we can explain ethical investors' behavior, for instance, by integrating positive effects for an ethical cause in their utility function (Beal, Goyen, and Phillips 2005, 72). In philosophical terms, I think we can best capture the nature of this particular kind of ethical investment by saying that the ethical investors are performing an action with a double intention. They do not only intend to make a future financial return, but also intend to promote some value they embrace or some normatively laden idea they hold.

Consider an example. If you use your money to buy shares of a certain corporation, intending to generate a future financial return for yourself, but at the same time also intending to thereby further feminism, this would then count as an instance of ethical investment. In principle, every ethical cause could form the basis for such an ethical investment. This broadening of scope is welcome. Narrower concepts like sustainable investment or (to 
a lesser extent) socially responsibly investment risk to obscure that there is a huge variety of ethical causes we can promote by investing our money in the right way, from feminism to equality or inclusion. ${ }^{7}$

What calling for a double intention does is to give us a clear idea of when and why a certain financial investment positively qualifies as ethical. Whenever you invest based on such a double intention you invest ethically precisely because you have this double intention. It also allows us to distinguish ethical investment from related practices.

On the one hand, ethical investment is unlike what one might call venture philanthropy (Köb 2018). Venture philanthropists give money to corporations (mostly start-ups) so as to generate a certain social impact. They are willing to do so without expecting any financial return. This is not to say that financial returns never ensue. But without the intended financial return for oneself, venture philanthropy is much closer to donating than to investing money. On the other hand, ethical investment as understood here is unlike shareholder activism (Sparkes 2001; Sandberg 2011). Like ethical investors, shareholder activists want to promote a certain cause. But how that goal connects to the investment made differs. Ethical investors seek to have a social impact by investing. By performing one action only, they simultaneously want to generate future financial returns and to have social impact. For shareholder activists, investing in certain companies only is a necessary means to then have social impact in a second step. Without being shareholders first, they cannot be shareholder activists actively seeking to influence corporate policies. ${ }^{8}$ Finally, the particularly direct connection between investing money and thereby creating social impact also is what distinguishes ethical investors from those who practice "classical" financial investment, to then donate (a part of) the proceeds. ${ }^{9}$ Again, what we see here are two distinct actions - one investment and one donation - rather than just one action - an ethical investment. ${ }^{10}$

\footnotetext{
${ }^{7}$ It is an independent question of whether all values are normatively suitable for ethical investment understood as action with a double intention. One might also wonder whether all values are equally practically suitable.

${ }^{8}$ Not all shareholder activism aims at having a social impact. There certainly are long-term and large investors who seek to actively influence corporate policies by using their power as shareholders, but who do so, for instance, in view of influencing that corporation's strategic decisions in ways they seem fit to increase long-run profitability (Ryan and Schneider 2002).

${ }^{9}$ This is closely related to the practice of "earning to give" (Singer 2015, ch. 4); see more on this below.

${ }^{10}$ Beal et al. $(2005,70)$ seem to suggest that we can also call those "ethical investors" who invest in ethically oriented mutual funds solely because this promises superior financial
} 
To summarize, conceiving of the positive qualifier of ethical investment in terms of requiring an action with a double intention allows us to make ethical investing an investment strictly speaking (i.e. with intended financial returns for ourselves), to emphasize that the good done is done by investing (and not by activism in corporate committees), and that we are dealing with one action only (rather than two separate ones, investment and donation, of which only the latter promises ethical worth).

Note that the role intentions play with respect to the negative and the positive qualifier is not analogous. As regards the negative qualifier, an investor's intentions for investing must look in a certain way to not morally taint the investment. We must not, for instance, intend to profit from morally tainted corporate practices, if we want that investment to be ethical. By contrast, as regards the positive qualifier, there has to be a second intention beyond the one to make a financial return to make the investment ethical.

While the stylized picture seems to suggest that investors, when investing ethically, either aim for a morally untainted investment or for investments which have a social impact, it remains a possibility to combine the two paradigms. Put differently, we can come up with a particularly demanding idea of what ethical investment requires by combining the two intentionbased qualifiers. In this case, ethical investments would only be those investments where our intentions for investing do not exhibit any kind of mens rea, and where we have the additional intention to further an ethical cause. ${ }^{11}$

While I think it is uncontroversial that combining the two paradigms would lead to a particularly demanding idea of what ethical investment requires, I think it is unclear which paradigm, on its own, is the more demanding one. Intuitively, one might feel like satisfying the negative qualifier is a negative moral duty of ours, while satisfying the positive qualifier is a positive duty. In addition, it seems to be a widely shared intuition that negative duties (like not to harm anyone) are for the most part easy to fulfil, whereas positive duties (like duties to aid) can be very demanding to fulfil (e.g. Lichtenberg 2010, 557-58). In fact, as Lichtenberg notes, it is precisely because "once we admit ... [positive] duties into the moral realm

performance. I think it is preferable not to call such investors "ethical investors" strictly speaking, but to use the more cumbersome formulation "investors in ethical funds". Why I think this will become clearer in the next section, where I discuss the issue of merely foreseeing (rather than intending) and ethical impact of one's investment.

${ }^{11} \mathrm{We}$ could make this idea of what ethical investment requires even more demanding by adding objective moral taint qualifiers, i.e. by not exclusively taking the investor's intentions into account when evaluating the investment. 
they threaten to take over and invade our lives ... [because of being] relentlessly demanding" $(2010,557)$, that the very existence of positive duties sometimes is disputed - and that, if their existence is conceded, they are mostly conceived of as limited or "imperfect" duties. All of this seems to support the idea that the positive qualifier is the more demanding one. It would then make sense to say that an investment which satisfies the negative qualifier at least is "not morally blameworthy", whereas an investment which satisfies the positive qualifier is "morally praiseworthy". Alas, Lichtenberg points out that there is something very wrong with this picture. Especially in a globalized world where everything is connected (and global financial markets are a prime example of this), "our most humdrum activities may harm people in myriad ways we have never thought about before ... [all the while being] seamlessly woven into our normal routines" $(2010,558)$. Lichtenberg proceeds to cogently argue that even to only fulfill our negative duties turns out to be very demanding and to require our undivided attention. Thus, I think we are well-advised to remain agnostic on the question of which paradigm for ethical investment, on its own, is more demanding.

\subsection{Ethical Investment, Intention, and Foresight}

There are two prominent worries one might have with respect to this salient role for intentions as regards the positive qualifier of ethical investment. First, why is it not enough to foresee (rather than intend) the positive effects? Second, what about cases in which we err, i.e. cases in which the intended positive effects never ensue?

In order to see why foresight is insufficient as a positive qualifier, it is important to understand what performing an action with a double intention quite generally means. If an action features a double intention, this means that we are trying to bring about two different effects by one action. But, as Walzer (1977) argues, actions which have two effects because of a double intention are different from actions which have intended effects and foreseen effects - as familiar from discussions of the doctrine of double effect (e.g. Aquinas Summa Theologica II-II, Q. 64, art. 7; Thomson 1976).

Against the background of strategic bombing cases as used in just war theory, Walzer argues that the doctrine of double effect actually is too lenient a moral principle for telling permissible strategic bombings from impermissible ones $(1977,151-59)$. He thinks that it is not enough not to intend the harm done to civilians (which constitutes a foreseen side effect). Instead, we must intend not to harm the civilians to make the bombing permissible. This is what Walzer refers to as the idea of double intention. 
The principle of double effect ... stands in need of correction. Double effect is defensible ... only when the two outcomes are the product of a double intention: first, that the 'good' be achieved; second, that the foreseeable evil be reduced as far as possible. ... Simply not to intend the death of civilians is too easy ... What we look for in such cases is some sign of a positive commitment to save civilian lives. (Walzer 1977, 155-56)

Walzer goes on to explain that a straightforward sign of such a positive commitment on the soldiers' part is if, for instance, they risk their own lives in order to save more civilian lives. This is because, by risking their own lives, they put their first intention (i.e. to harm the enemy) at risk in light of the second intention they have (i.e. to save civilians). They would not be willing to compromise their first intention in this way if they merely did not intend to harm civilians. Thus, for Walzer, choosing a course of action which weighs and balances two effects is a sign that we are acting with a double intention.

For now, we do not need to trouble ourselves with the moral implications of performing an action with a double intention. I only want to rely on Walzer's idea that the big difference between an action which features a pair of intention and non-intention (i.e. intended and foreseen effects) and an action which features a double intention (i.e. two different effects, both of which are intended), is that in the latter case we balancing effects. With this idea of balancing in place, I think there are two empirical arguments for why double intention makes for a meaningful positive qualifier of ethical investment.

First, many ethical investors are willing to sacrifice some financial return for making a positive social impact - and consider themselves ethical investors for precisely this reason (Mackenzie and Lewis 1999; Berry and Yeung 2013). Now some of these investors might believe they have to give up financial return when investing ethically for the wrong reasons. For instance, they might think that ethical investments underperform in comparison to more traditional ones, when there still is no conclusive data to this effect (Richardson and Cragg 2010; von Wallis and Klein 2015). Still, it remains true that many investors are willing to balance financial returns and positive effects for an ethical cause.

Second, commonsense perceptions about what it takes to be an ethical investor point in the direction that merely foreseeing positive effects for an ethical cause is not enough. Knobe's (2003) research in experimental philosophy highlights that people are more reluctant to ascribe intentional action if people claim to further some positive ethical cause than if they do 
some harm. Take the hypothetical situation in which the vice-president of some company says: "I don't care at all about helping the environment. I just want to make as much profit as I can. Let's start the new program". As Knobe reports, only 23 percent of the subjects confronted with this statement held that the vice-president intentionally helped the environment (2003). By contrast, if "help" was replaced with "harm", 82 percent held that the vice-president intentionally harmed the environment. As Knobe argues, "this effect is best explained in terms of the role that moral considerations play in people's concept of intentional action" $(2003,194)$. Another upshot is that we have to clear a particularly high bar to convince other people that we act ethically. The double intention-qualifier of ethical financial investment just reflects this. ${ }^{12}$

These two empirical arguments come down to how people intuitively conceive of ethical investment, i.e. to ordinary language arguments of some kind. Hudson (2005) on the other hand gives a theoretical argument that ethical investors cannot at the same time realize average market returns (i.e. that kind of return one usually makes when investing) and further an ethical cause by rewarding good companies by investing their money in them. One of Hudson's main ideas is that ethical investors are, as it were, always late to the party. They only start investing in companies once they "go ethical". But at this late point the notoriously fast financial market will already have factored in the effects of the ethical policy change on future corporate revenues; i.e. stock price will have risen if ethics indeed pays. Hudson concludes that

although ethical investors should make a rate of return related to systematic risk, they will not have any effect on corporations, and thus cannot punish bad (or reward good) corporations or affect corporate behavior. (Hudson 2005, 642)

This is a market-theoretical argument that investors cannot realize market returns on financial investments and further a certain ethical cause by rewarding good companies. Thus, ethical investors would need to balance these two goals - the most obvious approach being to sacrifice some financial return in view of thereby being able to create positive impact.

Apart from these empirical and theoretical arguments, there still is Walzer's normative argument in favor of double intention being required.

\footnotetext{
${ }^{12}$ Knobe's experiment only contrasts helping and harming scenarios for cases in which the vice-president denies having an intention other than to make profit. But it is plausible that these results transfer to cases in which the vice-president claims to have a double intention: to make profit and to help the environment.
} 
Closely tied to Walzer's description of what an action with a double intention is, there is an argument about the normative difference it makes to perform an action with a double intention. Although this is somewhat implicit in traditional formulations of the doctrine of double effect (cf. Mangan 1949, 43; Connell 1967, 1021), it is an essential part of the doctrine that ethical agents have to regret causing the foreseen harm. Put differently, it is

a misinterpretation to claim that the principle of double effect shows that agents may permissibly bring about harmful effects provided that they are merely foreseen side effects of promoting a good end. Applications of double effect always presuppose that some kind of proportionality condition has been satisfied. (McIntyre 2012)

In order for the doctrine of double effect to make a normative difference in how we evaluate a certain action, the proportionality condition needs to be satisfied; i.e. the agent must be disposed to avoid as much harm as possible. In this context, Walzer's terminology of performing an action with a double intention can be interpreted as one particularly promising way of expressing this aspect of the doctrine.

So this is the normative argument for why, to speak of making an ethical investment. It would be too easy to consider a certain financial investment ethical as soon as we intend to generate a financial return for ourselves, and also foresee that this will have good effects for, say, feminism. (Or even weaker: if we do not intend to outright hinder political, economic, personal, and social equality of sexes.) The good effects for the ethical cause must stand in good proportion to the financial return for ourselves. We need to be disposed to weigh them against each other to qualify as ethical investors.

To be sure, Walzer talks about balancing intended good effects and undesired bad effects so as to act ethically. This is not quite what we face in cases of ethical investment. Here we are talking about balancing good effects for ourselves (the financial return) and positive effects for some ethical cause. Still, I think that a kind of Walzerian argument in favor of a double intention applies to the case of ethical investment. Notably because there is no apparent reason for why intending rather than merely foreseeing something should only make a moral difference when we judge cases of harming (in contrast to helping). Experimental research like Knobe's merely suggests a difference in size as regards the moral difference made, not a complete disappearance. 
Note that it is an option to conceptually include double intentions as regards the definition of ethical investment, without also committing oneself to the idea that double intentions evaluatively matter. Committed consequentialists would deny that the distinction between performing an action with a double intention versus performing an action with a pair of intention and non-intention evaluatively matters. But such a consequentialist position is not entirely incompatible with my suggestions of taking into account investors' double intentions as regards ethical investment. We can keep metaphysical and normative considerations separate.

Those who think investor intentions make a normative difference may regard double intentions as an ethical qualifier. It is what makes investment ethically right. By contrast, those who think intentions do not matter evaluatively may regard double intentions as a purely conceptual qualifier. Put differently, the latter might accept that we can meaningfully call a certain investment an ethical investment in light of the investor's intentions. They could accept this, not because they think intentions are normatively important, but because they realize intentions play a role in ordinary language conceptions of ethical investment and make for a useful qualifier to distinguish ethical investment from related practices.

\subsection{Error Cases}

As a further objection to how a double intention makes a normative difference, one might think of error cases. Suppose there is some investor who buys shares of a tobacco company with the intention to financially profit and the intention to help cure lung cancer by investing in this company. Unless the tobacco company completely changes its business model, he is mistaken if he expects that his investment will further this particular ethical cause. But it seems that, based on double intentions as qualifier, we could say that his investment qualifies as ethical because he has the right intentions. This is counterintuitive.

Now, error cases like this have a long tradition as counterarguments to normative ethical theories stressing the importance of the intentions with which we act. This essay neither is the right place to settle this debate between consequentialist and deontologists, nor intended to do so.

However, there is an interesting elaboration of error case-objections which creates troubles that are idiosyncratic to the case of ethical investment. Suppose the old stock-objection and the small purchase-objection actually go through. This would mean that most ethical investors aiming at furthering a particular ethical cause by correspondingly investing their 
money would always be mistaken about the effects of their actions. Maybe not as obviously as the tobacco company investor aiming to cure lung cancer. But investors would constantly act based on a certain intention, but never achieve the intended goal. We would be dealing with a generalized "error theory" rather than with individual error cases. In such a scenario, would double intentions continue to make a normative difference?

I think the best reply to this objection just is to insist that we are not in a scenario in which ethical investments make no difference to corporate policies. Firstly, we need to acknowledge Irvine's above-mentioned, cogent replies to the old stock- and the small purchase-objection. In addition, I think that especially against the background of managers being rewarded based on short-run financial market performance, i.e. quarterly developments of a corporation's stock price, there is a straightforward way in which ethical investors can make a difference. Consider the following scenario. First, a company announces efforts to become (more) ethical. Second, this affects share price in two ways. On the one hand, if ethics pays, or is perceived to be paying, or is perceived to be a "must have" for corporations willing to remain in the market (if only for regulatory reasons), this positively affects share price. On the other hand, there is the increased demand for that stock by ethical investors which also drives stock price upward. As we are only considering the short run, even small changes in demand, which can be caused by market participants with comparatively little market power, matter. Third, this positive market feedback leads to positive feedback for the managers who decided to become more ethical. Fourth, the managers learn that they get rewarded if the company becomes more ethical. Fifth, they decide to make even more efforts to become even more ethical. And then the circle begins anew.

Finally, there is an entire class of consequentialist arguments wrestling with the problem that for collectively caused outcomes consequentialism seems to reach the wrong verdict. Think of climate change. While it is agreed that, if everybody flies a lot, this will contribute to global warming, one might have the impression that an individual's actions have no effect; because one person's emissions make no perceptible difference on a global scale, because the plane would have flown anyway irrespective of whether I am on board, and so on. Thus, it seems like the individual action of me flying to a conference cannot be considered wrong on consequentialist grounds - which seems problematic. But, for instance, Kagan (2011) provides a powerful argument against this conclusion. He stresses how the fact that our behavior might make a difference is enough for consequentialists to reach the right verdict. Even if the odds of me making a difference are small, as long as the effects in case I do make a difference are significant and negative, consequentialist calculus based on expected 
utility will reach the right conclusion; e.g. that I should not be flying to that conference.

Transferred to our context the argument would be that, even if it is unlikely that our ethical investment makes any difference with respect to which policies a corporation adopts, it might do so. Sometimes our purchase might be what tips the scales - which is why it is right (on consequentialist grounds) to make it. Consequently, also our intentions to promote a certain ethical cause by investing correspondingly cannot be considered to always be misguided.

\section{Ethical Investing and Ethical Giving}

If one adopts the idea of acting with a double intention as positive qualifier for ethical investment, this has interesting upshots. They are most clearly revealed if we compare ethical investment to a different practice with the declared goal to achieve positive ethical effects by reallocating money; namely, ethical giving as construed by effective altruists (e.g. MacAskill 2015; Singer 2015; Pummer 2016). In recent years, effective altruists have put forward arguments about how we should donate to charities. The general idea is simple and might be summarized like this: we ought to give a large amount of our income to those charities which most efficiently fight the most pressing normative issues.

There are some problems that effective altruism and ethical investment as understood in this essay share. The methodological worries effective altruists face, e.g. about observational bias or quantification bias (Gabriel 2017), are just as pressing for ethical investors. Also, for both giving and investing, they stand alongside hard to answer empirico-scientific questions of cause and effect. Only if we get the empirical aspect right, a donation or investment can do the good it is intended to do. Take the feminism example again. If we want to further feminism by investing our money, then we need high-quality empirical evidence as well as good theories to form a reliable picture of which activities of which corporations further feminism.

One classic historical case is that of the mechanization of housework, e.g. the advent of washing machines between the 1950s and 1970s. By drastically reducing the amount of time needed for washing, those corporations selling washing machines freed up time - which the women could use, for instance, for taking up a job of their own. Freeing women from housework, which is unpaid and typically not even recognized as work, is a positive effect those corporations achieve by selling what they 
sell. So investing in producers of washing machines and related devices should have seemed like a good option for ethical investment. However, the predicted effects never occurred. Although the time saving by using a washing machine was real, the advent of washing machines also led to a rise in hygiene standards. The time saved by washing faster was then spent to wash more than before (Kettschau 1990).

But there also are problems ethical investors have that effective altruists at least prima facie - do not need to trouble themselves with. These additional problems are a consequence of effective altruists not aiming for two (potentially conflicting) effects with their donations. A simple example highlighting the importance of this difference is to look at optimal giving. Arguably, the morally best strategy for donations is to give all of your income away, as even for your last dollar, those receiving it are very likely to have a higher marginal utility from it than you. By contrast, the maximally good investment cannot be to exclusively and maximally further the chosen ethical cause up to the point where there is no financial return left. This is for conceptual reasons. If you completely renounced on a financial return to maximally further the chosen ethical cause, we would not be dealing with an instance of ethical investment any longer. When practicing ethical investment, we need to consider two dimensions and reach balanced decisions.

At first one might think that, even if this complicates things, this is a problem effective altruists likewise know. After all, effective altruists are quite used to balancing two dimensions. For example, when they decide on whether to enter a certain (well-paying) career in order to "earn to give". Or when they decide how much of their overall income they want to give away. Effective altruists have come up with answers as to what to do in these cases (cf. Pummer 2016; Singer 2015; MacAskill 2015). But the decisions effective altruists face are not analogous to the ones ethical investors face.

Consider the "how much to give" decision. If we decide to economize so as to be able to spend 50 percent of our income on donations, then we do balance two dimensions. Namely, we balance considerations about how much we need to live a decent life with considerations about how much the money we economize would help others. This seems rather similar to the decision of how much financial return we are willing to sacrifice in order to also have a positive effect for a certain ethical cause. But the decisions are not analogous, as for the decision of "how much to give" the two dimensions are independent of each other. As effective altruist you can do the following thing. First, you decide on the place where your money should go to. That is, you select the best charity. Second, you decide 
whether to donate 30,40 , or 50 percent of your income to that charity. (Or the other way around.) How much you are willing to spend is independent from how effective your donation will be.

This is not the case for ethical investment. When investing ethically, you cannot first decide how much of your financial return you are willing to sacrifice and then decide on the best place to allocate that money. You necessarily make a decision in these two dimensions at once. When investing money ethically, each investment option is characterized by offering a pair of effects. One partial effect is your financial return. The other partial effect is the positive effect for an ethical cause.

Imagine the following scenario to illustrate this. In a first step, you decide that you are willing to accept a financial return on investment which is 50 percent lower than the average market return - say 3 percent instead of 6 percent. But when making this choice to accept a 3 percent return (but no less), you have considerably limited your set of options for your second choice, i.e. the choice of where your money should go to. Your preferred corporation from an ethical point of view, i.e. that corporation which most efficiently furthers your chosen ethical cause, might not be an investment option for you any longer. You might be unable to "afford" to invest in the best corporation, as it simply offers too low a financial return. In this sense, what used to be two independent choices is now one interdependent choice. You no longer separately decide on how much to give and where to give, you decide on a financial-and-ethical-effect pair. It is only the relative size of financial return to ethical effect you choose.

This might plausibly lead to hard choices. It might lead to hard choices in the sense that, in whichever way you decide, you cannot achieve all of your goals. For instance, you might find yourself in a situation in which, in order to invest in that corporation you deem best from an ethical point of you, you need to make even harsher economizations in your retirement savings. This is particularly problematic as corporations promoting those ethical causes typically favored by effective altruists tend to offer comparably low financial returns. There just is not much money to be made in fighting diseases which predominantly affect the poor. This is why such endeavors are in need of donations in the first place.

This might also lead to hard choices in the sense of choices which are psychologically harder to make. Consider Singer $(2015,28-31)$ telling the story of Julia, an enthusiastic effective altruist struggling with the fact that her commitment to effective altruism seems to imply that she cannot have an ice cream from time to time. 
When shopping, she would constantly ask herself, 'Do I need this ice cream as much as a woman living in poverty elsewhere in the world needs to get her child vaccinated?' That made grocery shopping a maddening experience, so she and ... [her husband] made a decision about what they would give away over the next six months and then drew up a budget based on what was left. Within that budget, they regarded the money as theirs, to spend on themselves. Now Julia doesn't scrimp on ice cream because, as she told the class, 'Ice cream is really important to my happiness.' (Singer 2015, 29-30)

It is easy to see how big a psychological relief Julia's solution of drawing up a budget and spending 50 percent - no more, no less - of her income on donations is. In abstract terms, this is a form of cognitive unburdening. We decide once how much we want to spend, and do not have to deal with the worry of violating the consequentialist principle of agent-neutrality for some time. Unfortunately, this is not something ethical investors can do. For each investment choice they make they are confronted with how they can do even more good. Consequentialism's demandingness hits them with full force (cf. Chappell 2009).

In principle, there are no theoretical problems that keep consequentialists from reaching reasoned conclusions about which financial-return-ethicaleffect pair is the best. After all, both dimensions of ethical investments arguably can be expressed in some form of utilitarian calculus. Yet, given that each investment option features such a pair, the need for a systematic way to address agent-neutrality - and to justify why it might be alright to sacrifice this consequentialist tenet from time to time (as Julia does) - is exceedingly pressing for ethical investment.

Finally, the situation might not only lead to hard choices for ethical investors, but also for those aiming to run their firms ethically. Consider that in order to be a viable investment option, entrepreneurs might face the choice of doing less good to create higher financial returns. For only if they generate at least a "sufficient" financial return, they will appear on the radar of those seeking to invest ethically. This is an extremely pernicious effect. In order to attract more money for their ethical cause they have to be, so to speak, less ethical. Not in the sense of being less efficient in fighting poverty or diseases. But in simply allocating less money for these activities and reserving more money to pay dividends to investors. The mechanics just described might ultimately mean that there is a set of typical organizations which qualify for ethical investment purposes and a set of typical organizations which qualify for ethical giving, with the two sets not overlapping. 


\subsection{A Positive Upshot}

Because dealing with worries of agent-neutrality and demandingness is more complicated when we aim to invest rather than to give ethically, one might feel like getting ethical investment right is more difficult than getting ethical giving right. And yet, if we invest ethically, good things follow.

First, consider that there is much more money going round seeking to be invested than seeking to be donated (von Wallis and Klein 2015, 62). This is because many of those seeking to allocate considerable amounts of money are bound by fiduciary duties not to simply donate but to invest the money at their disposal. This means that, judging by the amount of money to be allocated, the potential impact of ethical investing by far exceeds that of ethical giving.

Second, if ethical investment were practiced widely, it would plausibly have a systemic impact - which some people accuse effective altruists of not paying enough attention to (Srinivasan 2015). Like ethical consumerism does, practicing ethical investment forces corporations to thoroughly rethink their business. That is to say, it does more than just to redistribute money.

Most notably, however, ethical investment furthers honesty about what it means and entails to promote ethical causes by re-allocating money - in a way that ethical giving does not. Ethical investment might be hard and messy. But it is more honest in the sense that the option of compartmentalization practiced by Singer's Julia - seemingly endorsed by some effective altruists - is not even on the table. What I mean by this is that we can reasonably accuse Julia of falling prey to the moral variant of the well-known cognitive bias of mental accounting. Namely, to allow ourselves a "little immorality" here and there in light of having done something moral first (Sachdeva, Iliev, and Medin 2009; Merritt, Effron, and Monin 2010). Investing money with a double intention does not accommodate such hand-waving, but sharply highlights the normative troubles we need to deal with. It highlights normative troubles that effective altruists only prima facie do not have to troubles themselves with.

\section{REFERENCES}

Aquinas, T. 1988. On Law, Morality, and Politics. Eds. William P. Baumgarth and Richard J. Regan. 2nd ed. Indianapolis \& Cambridge: Hackett. 
Beal, D. J., M. Goyen, and P. Phillips. 2005. Why Do We Invest Ethically? Journal of Investing 14: 66-77.

Berry, R. H., and F. Yeung. 2013. Are Investors Willing to Sacrifice Cash for Morality. Journal of Business Ethics 117: 477-942.

de Bruin, B., L. Herzog, M. O’Neill, and J. Sandberg. 2018. Philosophy of Money and Finance. In The Stanford Encyclopedia of Philosophy (Winter 2018 Edition), ed. Edward N. Zalta. https://plato.stanford.edu/archives/win2018/entries/moneyfinance/.

Chappell, T., ed. 2009. The Problem of Moral Demandingness. Basingstoke: Palgrave Macmillan.

Connell, F. J. 1967. Double Effect, Principle Of. In New Catholic Encyclopedia, 4:1020-1022. New York: McGraw-Hill.

Duff, R. A. 1990. Can I Help You? Accessorial Liability and the Intention to Assist. Legal Studies 10: 165-181.

Duff, R. A. 2007. Answering for Crime: Responsibility and Liability in the Criminal Law. Oxford: Hart Publishing.

Gabriel, I. 2017. Effective Altruism and Its Critics. Journal of Applied Philosophy 34: 457-473.

Hudson, R. 2005. Ethical Investing: Ethical Investors and Managers. Business Ethics Quarterly 15: 641-657.

Irvine, W. B. 1987. The Ethics of Investing. Journal of Business Ethics 6: 233-242.

Kagan, S. 2011. Do I Make a Difference? Philosophy and Public Affairs 39: 105-141.

Kettschau, I. 1990. Gewonnene Zeit - Zerronnene Zeit. In Haushaltsträume. Ein Jahrhundert Technisierung Und Rationalisierung Im Haushalt, ed. Hans Köster, 161-173. Königstein.

Knobe, J. 2003. Intentional Action and Side Effects in Ordinary Language. Analysis 63: 190-194.

Köb, Johanna. 2018. Current trends in sustainable investing - an interview with Zurich Insurance's Head of Responsible Investment.

Langtry, B. 2002. The Ethics of Shareholding. Journal of Business Ethics 16: $397-400$.

Larmer, R. 1997. The Ethics of Investing: A Reply to Irvine. Journal of Business Ethics 16: 397-400. 
Lewis, A., and C. Mackenzie. 2000. Support for Investor Activism among UK Ethical Investors. Journal of Business Ethics 24: 215-222.

Leys, J., W. Vandekerckhove, and L. Van Liedekerke. 2009. A Puzzle in SRI: The Investor and the Judge. Journal of Business Ethics 84: 221-235.

Lichtenberg, J. 2010. Negative Duties, Positive Duties, and the 'New Harms.' Ethics 120: 557-578.

MacAskill, W. 2015. Doing Good Better - How Effective Altruism Can Help You Make a Difference. New York: Gotham Books.

Mackenzie, C. 1997. Ethical Investment and the Challenge of Corporate Reform. Bath: University of Bath. http://staff.bath.ac.uk/hssal/crm/.

Mackenzie, C., and A. Lewis. 1999. Morals and Markets: The Case of Ethical Investing. Business Ethics Quarterly 9: 439-452.

Mangan, J. 1949. An Historical Analysis of the Principle of Double Effect. Theological Studies 10: 41-61.

McIntyre, A. 2012. Doctrine of Double Effect. In The Stanford Encyclopedia of Philosophy (Fall 2011 Edition), ed. E. N. Zalta. http://plato.stanford.edu/archives/fall2011/entries/doubleeffect/.

Merritt, A. C., D. A. Effron, and B. Monin. 2010. Moral Self-Licensing: When Being Good Frees Us to Be Bad. Social and Personality Psychology Compass 4: 344-357.

Moore, M. S. 2007. Causing, Aiding, and the Superfluity of Accomplice Liability. University of Pennsylvania Law Review 156: 395-452.

Moore, M. S. 2007. 2009. Causation and Responsibility. Oxford: Oxford University Press.

Pummer, T. 2016. Whether and Where to Give. Philosophy \& Public Affairs 44: 77-95.

Richardson, B. J., and W. Cragg. 2010. Being Virtuous and Prosperous: SRI's Conflicting Goals. Journal of Business Ethics 92 (supp. 1): 21-39.

Ryan, L. V., and M. Schneider. 2002. The Antecedents of Institutional Investor Activism. The Academy of Management Review 27: 554-573.

Sachdeva, S., R. Iliev, and D. L. Medin. 2009. Sinning Saints and Saintly Sinners: The Paradox of Moral Self-Regulation. Psychological Science 20: 523-28. 
Sandberg, J. 2008. The Ethics of Investing. Making Money or Making a Difference? Gothenburg: Acta Universitatis Gothoburgensis.

Sandberg, J. 2011. Changing the World through Shareholder Acticism? Nordic Journal of Applied Ethics 5: 51-78.

Sandbu, M. E. 2012. Stakeholder Duties: On the Moral Responsibility of Corporate Investors. Journal of Business Ethics 109: 97-107.

Singer, P. 2015. The Most Good You Can Do - How Effective Altruism Is Changing Ideas About Living Ethically. New Haven and London: Yale University Press.

Sparkes, R. 2001. Ethical Investment: Whose Ethics, Which Investment? Business Ethics: A European Review 10: 194-205.

Srinivasan, A. 2015. Stop the Robot Apocalypse, Review of Doing Good Better: Effective Altruism and a Radical New Way to Make a Difference, by William MacAskill. London Review of Books 37: 3-6.

Thomson, J. J. 1976. Killing, Letting Die, and the Trolley Problem. The Monist 59: 204-217.

Wallis, M. von, and C. Klein. 2015. Ethical Requirement and Financial Interest: A Literature Review on Socially Responsible Investing. Business Research 8: 61-98.

Walzer, M. 1977. Just and Unjust Wars. New York: Basic Books. 